\title{
Organo-halide Carcinogen
}

National Cancer Institute

\section{Source}

National Cancer Institute. Organo-halide Carcinogen. NCI Thesaurus. Code C45183.

A compound with carcinogenic activity that has a carbon-based backbone that may be a cyclic or non-cyclic structure with single, double or triple bonds and can have other elements besides hydrogen incorporated in its structure but has at least one halogen (chloride, bromide, fluoride, iodide, and astatine) atom substituted for one of the hydrogen atoms. ( $\mathrm{NCl05)}$ 